\title{
STVDIVM. REVISTA DE HUMANIDADES
}

La Facultad de Ciencias Sociales y Humanas de la Universidad de Zaragoza ofrece a la comunidad científica Stvdivm. Revista de Humanidades, creada en 1995 como resultado de la fusión de dos publicaciones periódicas, - Studium. Geografía, historia, arte, filosofía y Studium. Filología-, producidas desde 1984 en el entonces denominado Colegio Universitario de Teruel. Desde sus inicios, la revista cuenta con un consejo de redacción o comité editorial, un consejo científico y una cartera de expertos que actúan como evaluadores externos de los originales recibidos.

El Consejo de Redacción de Stvdivm. Revista de Humanidades se ocupa de la edición, difusión y gestión de cada nuevo volumen, ajustándose en este cometido a los criterios y buenos usos para la presentación de publicaciones periódicas recomendados desde el Centro de Información y Documentación Científica del CSIC y desde los organismos internacionales como ISO, AENOR, UNE o el PGI de UNESCO.

Con el objetivo de difundir y fomentar el estudio y la investigación de las Humanidades desde unos presupuestos multidisciplinarios, el Consejo de Redacción admite la publicación de trabajos sobre cualquiera de las materias propias de las Humanidades. Para mantener la calidad científica de Stvdivm, los artículos recibidos son revisados por, al menos, dos evaluadores externos (peer review). Con esta misión, la revista cuenta con la colaboración del Consejo Científico y de una veintena de investigadores y especialistas de reconocido prestigio tanto en el ámbito nacional como internacional.

A través de intercambios y suscripciones y de la distribución que realiza Prensas de la Universidad de Zaragoza, Stvdivm. Revista de Humanidades tiene una amplia difusión dentro de España y en distintos países europeos y americanos. Esta política editorial permite que la revista y sus contenidos estén presentes en distintos servicios nacionales e internacionales de indización, resumen, información bibliográfica y documentación científica en el ámbito humanístico tales como ISOC, REBIUN, Latindex, CINDOC, MLA International Bibliography Database, MLA Directory of Periodicals, Dialnet o Regesta Imperii.

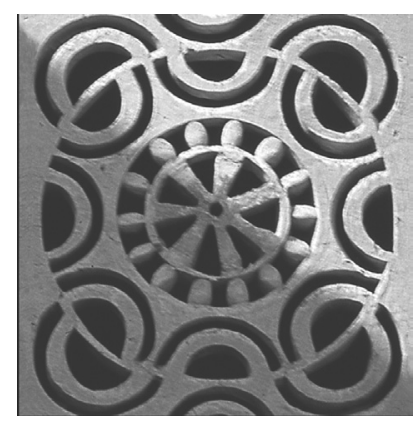




\section{STVDIVM. REVISTA DE HUMANIDADES}

Stvdivm. Revista de humanidades is a fully peer-reviewed journal edited by the Faculty of Social Sciences and Humanities at the Universidad de Zaragoza. Studium began in 1995 as a result of the merger of two previous publications-Studium. Geografía, historia, arte, filosofía and Studium. Filología- issued since 1984 by the now extinct University College Teruel. Since its launch, Studium consists of an Editorial Board, a Scientific Board, and a board of independent reviewing editors that assess all the manuscripts submitted to the journal.

The Editorial Board of Stvdivm. Revista de Humanidades coordinates the edition, diffusion, and administration of each new volume according to the criteria for the presentation of periodical publications recommended by the Spanish National Research Council's Centre for Scientific Information and Documentation and by international organisms such as ISO, AENOR, or Unesco/PGI.

With the objective of spreading and promoting study and research in the field of Humanities from a multidisciplinary viewpoint, the Editorial Board accepts the publication of articles on any subject related to the humanities. In order to maintain high quality standards, the manuscripts submitted to Studium are reviewed, at least, by two members of our board of reviewing editors, all of whom are external, recognised researchers and specialists, both national and international.

Through subscriptions, exchanges, and the distribution carried out by the University of Zaragoza Press, Stvdivm can be found not only in Spain but also in many European and American countries. This editorial policy has enabled the journal and its contents to be present in different national and international services dealing with indexation, summary, bibliographic information, and scientific documentation in the field of Humanities, some of them being ISOC, REBIUN, Latindex, CINDOC, MLA International Bibliography Database, MLA Directory of Periodicals, Dialnet, or Regesta Imperii.

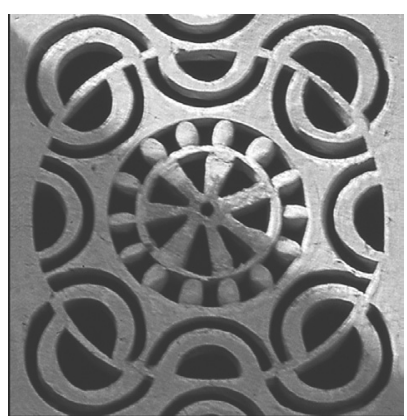




\section{NORMAS PARA LA PRESENTACIÓN DE ORIGINALES}

Stvdivm. Revista de Humanidades admite para su publicación trabajos originales, revisiones bibliográficas, reseñas sobre obras de reciente aparición y comentarios de libros, tanto en castellano como en otros idiomas. Los autores y las editoriales podrán enviar sus publicaciones a la dirección postal de la revista a fin de que el Consejo de Redacción estime la pertinencia de su inclusión en la sección de reseñas y comentarios de libros.

En los artículos y trabajos enviados cada autor hará constar en folio aparte los siguientes datos: nombre y apellidos, dirección postal completa, dirección electrónica, títulos académicos, categoría profesional, adscripción académica y fecha de entrega de la colaboración.

La extensión de los artículos deberá oscilar entre las 20 y 25 páginas escritas en DIN A-4, con tipo de letra Times 12 y separadas por un espacio interlineal de 1.5. Las páginas irán numeradas e incluirán las notas a pie de página escritas en Times 9 y separadas por un solo espacio interlineal. Deben contener:

1) título del trabajo en el idioma del texto y su versión inglesa;

2) nombre y adscripción institucional del autor o autores;

3) resumen en castellano e inglés de hasta 200 palabras que contenga los aspectos y resultados esenciales del trabajo; estos resúmenes se escribirán sin punto y aparte y no contendrán tablas, gráficos ni referencias bibliográficas;

4) palabras clave en el idioma del texto y en inglés.

En la redacción de los estudios se recomienda seguir el esquema general de los trabajos de investigación: a) introducción que exponga los fundamentos del trabajo y especifique claramente sus objetivos; b) descripción de las fuentes, métodos y materiales empleados en su realización; c) exposición de los resultados y discusión de los mismos; d) conclusiones finales. Podrán añadirse los apéndices que se consideren necesarios.

Si el artículo contiene figuras y/o tablas, se adjuntarán en documento aparte, siendo necesario indicar con claridad el lugar del texto donde deben ir colocadas. Irán numeradas y llevarán un encabezamiento conciso. Las tablas se numerarán con números romanos (Tabla I) y las figuras con números arábigos (Figura 1).

Las referencias bibliográficas incluidas en las notas se harán constar en minúscula según la siguiente estructura:

Fernando López Rajadel, 1994, Crónicas de los jueces de Teruel (1176-1532). Teruel, Instituto de Estudios Turolenses.

Jaime Caruana Gómez de Barreda, 1953, «Organización de Teruel en el siglo XII», Teruel, 10: 9-108.

María del Mar Agudo Romeo, 2000, «El combate judicial en el fuero de Teruel». En José Manuel Latorre Ciria, coord., Los fueros de Teruel y Albarracín. Teruel, Instituto de Estudios Turolenses: 77-86. 
En caso de bibliografía al final del artículo, se limitará a las obras citadas en el texto. Se invertirá la mención de autoría (apellidos, nombre) con objeto de ordenar alfabéticamente las obras según el apellido de su autor. Si se opta por el sistema Harvard, el año de edición se colocará a continuación de la mención de autoría y se separará por una coma del título del libro o artículo.

Se seguirán las normas de publicación habituales en las ediciones científicas en cuanto al uso de signos de puntuación, mayúsculas, versalitas, cursivas, negritas, abreviaturas, cantidades, citas en párrafo aparte y entrecomillados así como en cualquier otro aspecto que no halla sido especificado en estas líneas.

Con la intención de facilitar la elaboración técnica del volumen, las colaboraciones se remitirán en soporte electrónico, pudiendo utilizar para ello tanto la dirección postal como el correo electrónico de la revista: studium@unizar.es El autor enviará, además, una copia del artículo en papel, sin que figure su nombre, con objeto de ser remitida a los evaluadores externos encargados de realizar los informes solicitados por el Consejo de Redacción.

Cada autor recibirá un ejemplar de la revista y diez separatas de su trabajo. El Consejo de Redacción de Stvdivm. Revista de Humanidades no mantendrá correspondencia con los autores de los artículos no aceptados para su publicación, no se verá obligado a dar explicaciones sobre las circunstancias de su rechazo ni dará a conocer los informes sobre los mismos. De no ser aceptados para su publicación, los trabajos remitidos solo serán devueltos a petición expresa de sus autores, previo envío del franqueo necesario.

\section{Correspondencia y recepción de colaboraciones:}

Stodivm. Revista de Humanidades

Facultad de Ciencias Sociales y Humanas

Universidad de Zaragoza

C/ Atarazana, s/n - Campus Universitario

44.003 TERUEL

Tel: +34 978618100

Fax: +34 978608103

studium@unizar.es

\section{Página web de la revista:}

http://studium.unizar.es 


\section{MANUSCRIPTS SUBMISSION}

Stvdivm. Revista de Humanidades publishes critical, historical, and theoretical essays, bibliographical examinations, book reviews, and interviews in Spanish as well as in other languages. All manuscripts should be submitted to the journal's postal address. They will be subject to a prescreening and formal review process.

To be considered, the following information of the author must be included: first name, family name, full postal address, e-mail address, professional category, academic degree, and date of submission.

Submissions ought to be between 20-25 DIN A4 pages long written in Times $12 \mathrm{pt}$. and 1.5 interlinear space. Pages should be numbered and footnotes should be written in Times 9 pt. and single interlinear space. They should include:

1) Title (both in the language of the main text and in English);

2) Name and institution of the author(s);

3) Abstract (both in the language of the main text and in English). Abstracts ought to be one single paragraph of no more than 200 words and should not have tables, illustrations or bibliographical references;

4) Key words (both in the language of the main text and in English).

Authors are recommended to adhere to the following format for the writing of research studies: a) introduction containing the foundations and the objectives of the study; b) descriptions of resources, methodology, and materials used; c) presentation of results and discussion; d) conclusion. All appendixes considered necessary can be added to the study.

Tables and figures should not be embedded in the text, but should be included as a separate file, and the place where they are to appear in the text should be clearly indicated. They should be numbered and include a short descriptive title. Roman numerals (Table I) should be used for tables and Arabic numerals (Figure 1) for figures and illustrations.

Bibliographical references included in the notes should be written in lower-case letters following this structure:

Fernando López Rajadel, 1994, Crónicas de los jueces de Teruel (1176-1532). Teruel, Instituto de Estudios Turolenses.

Jaime Caruana Gómez de Barreda, 1953, «Organización de Teruel en el siglo XII», Teruel, 10: 9-108.

María del Mar Agudo Romeo, 2000, «El combate judicial en el fuero de Teruel». En José Manuel Latorre Ciria, coord., Los fueros de Teruel y Albarracín. Teruel, Instituto de Estudios Turolenses: 77-86. 
The bibliography at the end of the article should only indicate works quoted in the text. The mention of authors should be inverted (surname, name) so that they can be ordered alphabetically according to the last name of the authors. If using Harvard style, the year of publication should appear after the name of the author and should be separated from the title of the book or article by a comma.

Authors are kindly requested to abide by the publication rules that are customary in scientific literature when it comes to the use of punctuation marks, capital letters, small capitals, italics, bold letters, abbreviations, quantities, quotations in separate paragraphs and in inverted commas, or any other aspect not specified here.

With the aim of facilitating the technical elaboration of each volume, collaborations should be submitted electronically either to the postal or the e-mail address of the journal (studium@unizar.es). The author(s) should also submit a printed version of the article, in which all information identifying the author should have be removed so that it can be sent anonymously to referees.

Each author will receive a copy of the issue and fifteen offprints of their article. The Editorial Board of Stvdivm. Revista de Humanidades does not keep correspondence with the authors of the articles that have not been accepted for publication, does not give explanations about the reasons for their rejection, and does not show the reports of the articles. If an article is not accepted for publication, it will only be returned if the author requests it and provides the necessary postage.

\section{Send manuscripts to:}

Stvdivm. Revista de Humanidades

Facultad de Ciencias Sociales y Humanas

Universidad de Zaragoza

C/ Atarazana, s/n - Campus Universitario

44.003 TERUEL

Tel: +34978618100

Fax: +34 978608103

studium@unizar.es

\section{Website:}

http://studium.unizar.es 


\section{BOLETÍN DE INTERCAMBIO}

Deseamos iniciar y mantener intercambio con Studium. Revista de Humanidades, de la que deseamos recibir volúmenes anuales, a partir del número

NOMBRE

UNIVERSIDAD/ORGANISMO

$\mathrm{DNI} / \mathrm{NIF}$ TELÉFONO

DIRECCIÓN

POBLACIÓN

C.P.

PAÍS

PRECIO DE CADA NÚMERO SUELTO: 12 Euros.

A cambio, les remitiremos automáticamente volúmenes anuales de la Revista , que se publica con una periodicidad:
$凶$ trimestral
凶 semestral
$凶$ anualmente

(táchese lo que no proceda)

a partir del número , para lo que les enviamos junto con este Boletín un ejemplar gratuito de muestra. Renovaremos el intercambio para cada nuevo volumen mientras no se dé orden expresa de lo contrario.

Esta propuesta de intercambio será sometida a la aprobación del Consejo de Redacción de Studium. Revista de Humanidades de la Facultad de Ciencias Sociales y Humanas (Universidad de Zaragoza).

Enviar a: SERVICIO DE PUBLICACIONES DE LA UNIVERSIDAD DE ZARAGOZA Edificio de Geológicas. C/ Pedro Cerbuna, 21. 50009 ZARAGOZA Tfno. 976761330 Fax: 976761063 


\section{BOLETÍN DE PEDIDO}

Deseo recibir los números atrasados de la revista Studium. Revista de Humanidades indicados a continuación:

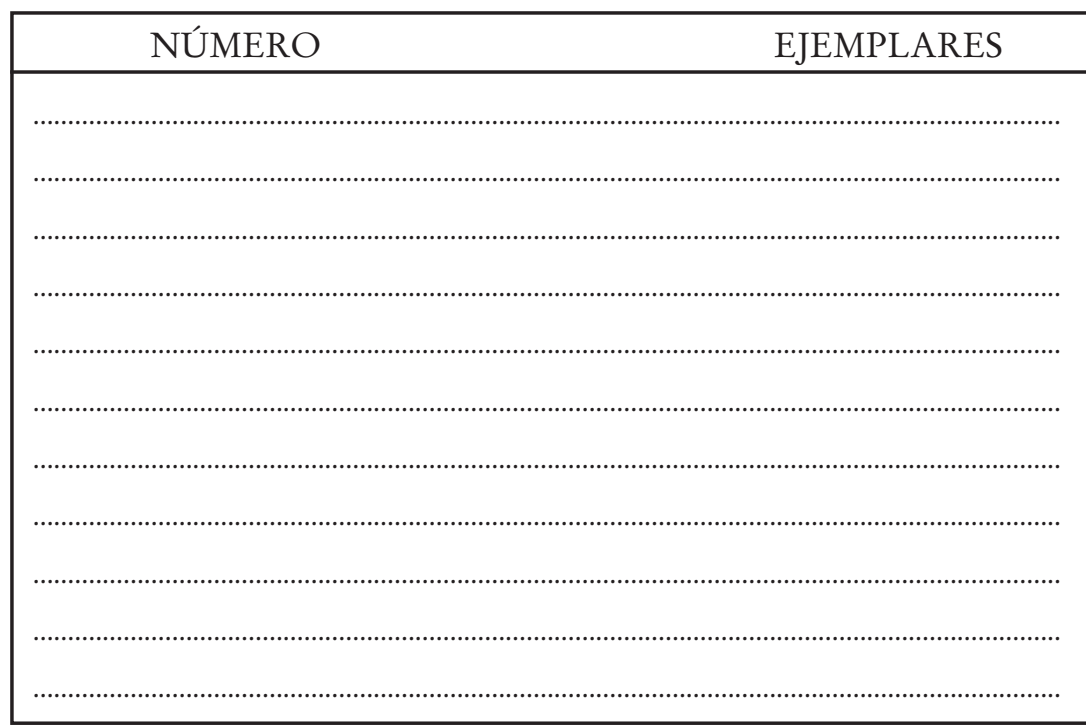

NOMBRE

UNIVERSIDAD/ORGANISMO

$\mathrm{DNI} / \mathrm{NIF}$ ...TELÉFONO

DIRECCIÓN

POBLACIÓN C.P. PAÍS

PRECIO DE CADA NÚMERO SUELTO: 12 Euros.

Enviar a: SERVICIO DE PUBLICACIONES DE LA UNIVERSIDAD DE ZARAGOZA Edificio de Geológicas. C/ Pedro Cerbuna, 21. 50009 ZARAGOZA Tfno. 976761330 Fax: 976761063 


\section{BOLETÍN DE SUSCRIPCIÓN}

Deseo suscribirme a Studium. Revista de Humanidades de la que recibiré

volúmenes anuales, a partir del número

NOMBRE

UNIVERSIDAD/ORGANISMO

$\mathrm{DNI} / \mathrm{NIF}$

TELÉFONO

DIRECCIÓN

POBLACIÓN

C.P.

PAÍS

PRECIO DE CADA NÚMERO SUELTO: 12 Euros.

Precio de suscripción: 18 Euros anuales (incluye los números misceláneos de la revista y los números monográficos).

Marque con una $\mathrm{X}$ la forma de pago:

Pago contrarreembolso (solo para España).

Cheque a nombre de Studium. Revista de Humanidades.

Giro Postal

Transferencia bancaria a nombre de Studium. Revista de Humanidades.

Servicio de Publicaciones de la Universidad de Zaragoza. 